\title{
The benefits of non-motorized transport in the city of Rio de Janeiro
}

\author{
L. Basto \& N. Moraes \\ Energy Planning Program, Federal University of Rio de Janeiro, \\ UFRJ, Brazil
}

\begin{abstract}
The Brazilian light vehicle fleet's consumption of gasoline in 2008 was equivalent to 136.5 million barrels of petrol. This volume of consumption is expected to increase significantly during the coming years, having in mind, among other factors, the country's low motorization rate (89 cars/1000 people) compared with developed countries such as the U.S. (776 cars/1000 people). The increase in the motorization rate is linked to external negative factors such as air pollution, congestion, accidents and the increase in urban traffic space. This article examines the alternative of reducing car use through its substitution by non-motorized transport, in particular the bicycle, and evaluates the principle benefits to be derived there from. The subject area covered in this study is the city of Rio de Janeiro, in particular the South Zone and City Center which are linked by bicycle routes and whose populations are receptive to the use of the bicycle as a means of transport. The methodology takes into account local population figures, income, vehicle fleets and urban mobility. The study shows that, of the total of 1.4 billion kilometers driven by cars per year, there is potential for the substitution of $28.5 \%$ by bicycles. Such substitution would represent, in the area under study, a reduction in gasoline consumption of 62 million liters per year, avoiding the emission of 140 thousand tons of $\mathrm{CO}_{2}$. Additionally, it is also estimated that the cost of car accidents could be reduced by $\mathrm{R} \$ 41$ million, while around $\mathrm{R} \$ 156$ million/year of consumer spending on fuel would be eliminated. Increasing bicycle use in Rio de Janeiro would be socially inclusive and would soon eliminate car-related external negative factors, apart from restoring and maintaining the physical and mental well being of the population.
\end{abstract}

Keywords: non-motorized transport, bicycle, $\mathrm{CO}_{2}$ emission, sustainable mobility. 


\section{Introduction}

Mobility is known worldwide as an essential basic requirement for a better standard of living. An increase in personal mobility allows access to essential services as well as to leisure activities. In the same time mobility is part of a modern lifestyle and expands the choice of where to life. The large increase in the number of cars in the last centuries is one of the most important indicators for this desire. Private vehicles provide their owners an unprecedented flexibility in what-, and when-ever, they want to do

However, despite the increasing mobility, the development of worldwide passenger transport focused on individual transport (automobile) is related to a very high inefficiency especially considering aspects of energy consume and environmental impacts (atmosphere and noise pollution). Beyond, other factors associated with the intensive use of cars must be considered, such as: the wasteful use of urban space (because of the growing need of infrastructure), the risk of accidents and all the energy consumption and pollution caused by the automobile production chain.

There are numerous proposals to increase the efficiency in the transport sector as well as to reduce of the negative consequences they cause, especially the emission of greenhouse gases and fuel consumption. However, the majority of these proposals have been focused on technological measures which mitigate a single problem, like the reduction of emissions through catalytic converters. In an isolated view these measures seem to be an effective cost manner to reach environmental goals. However, through the perspective of the society, a lot of other environmental objectives are not being solved. According to the article "Transport at a Cross Road" published by the European Environment Agency, in 2009, the most effective measures are those which solve different problems at the same time [1].

Within this concept of measures the ones with the best results where these, including replacement of conventional transport as: virtual access, telecommunications, urban restructuring which promotes short distances between residences and work places, cycling and hiking [2]. Investments in a more diverse transport system, which promotes variable choices for walking and cycling and the use of public instead of individual transport result in a much more efficient use of transport resources.

The mainly objective of this study, is to quantify some of the benefits of nonmotorized transport, particularly by bicycle, in the case of Rio de Janeiro city (Brazil). The second topic of the paper describes the situation in Brazil, in respect of the motorization rate and the importance of incorporating nonmotorized transport in urban planning. The third topic discusses characteristics of Rio de Janeiro and, specifically, the researched area, and indicates the purposes that the city is suitable for a program to increase the use of bicycles, as a mean of transport in order to replace cars. In the fourth and fifth topics are presented the methodology and the results, respectively. Finally, there is a conclusion. 


\section{Motorization in Brazil}

Although the circumstances of the current transport system indicates a real need of changes, in terms of technology, energy, environment and space, the forecasted growth in the private car segment indicates that the actual tendency will be sustained, especially among the non-OECD countries (Organization for economic cooperation and development), including Brazil.

In the case of Brazil, the lightweight car fleet consumed a volume of gasoline equivalent of 136.5 million barrels of oil in 2008 [3]. This volume should increase expressively in the upcoming years, bearing in mind, among other factors, the still very low motorization rate of the country (89 cars/1000 people) compared with developed countries such as the USA (776 automobiles/thousand people).

At this point, should be emphasized the influence of per capita income to the growth of the passengers transport. While the transport system is modernized and the per capita income increases, the possession of private automobiles increases as well [5]. Considering that Brazil still presents a low per capita income, compared with OCDE countries, the growth potential related to the fleet is large.

Figure 1 shows the motorization rate over the average income per inhabitant. Countries such as China, Brazil and Russia, whose per capita income was less than 10 thousand dollars in 2007, present a motorization rate of less than 300 cars per 1000 inhabitants. On the other hand, countries with an income of more than 15 thousand dollars in 2007 (Japan, Germany, Greece, Portugal, Spain,

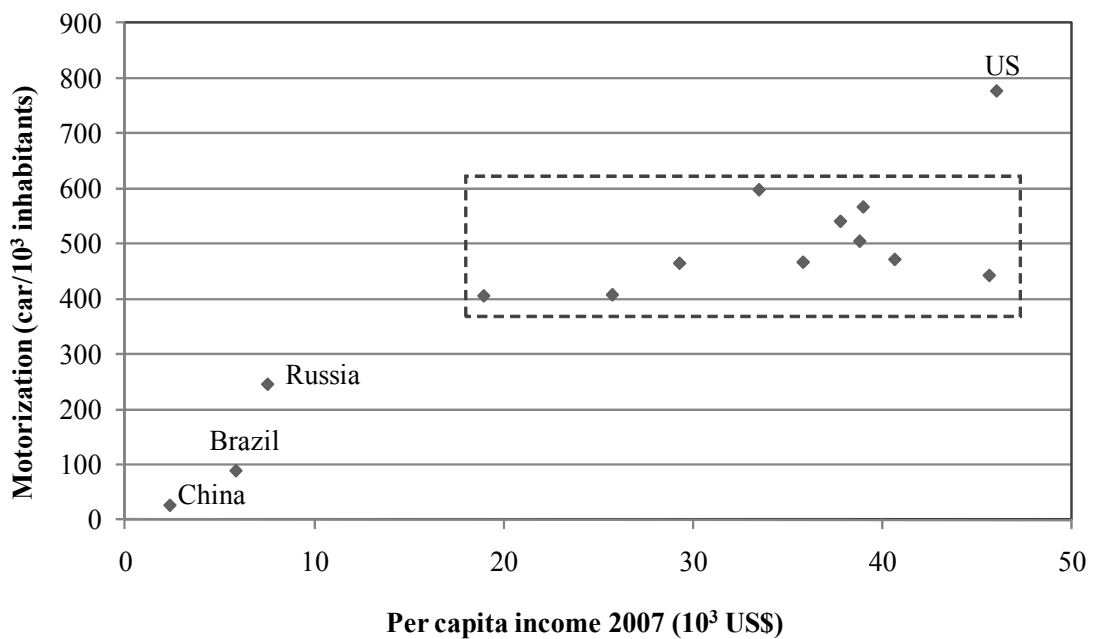

Figure 1: Motorization rate over the average income per inhabitant in selected countries (2007). 
France, Italy, the Netherlands, England and countries belonging to EU-27) present motorization rates of more than 400 cars per 1000 inhabitants. The USA, whose per capita income was around 46 thousand dollars in 2007, presents an motorization rate around 800 cars per 1000 inhabitants [7, 8]. These countries are presented in Figure 1 inside the box. The USA, whose per capita income was around 46 thousand dollars in 2007, presented motorization around 800 cars per 1000 inhabitants [6].

Expecting an expressive growth of the motorization rate in developing countries, including Brazil, roads become each time more insufficient to handle the expanding number of private cars and people walking or going out by bicycle [9].

The political understanding about this reality in Brazil, resulted in 2003, in the creation of the Ministry of Cities, which was build to consider the union of the most relevant and strategic areas in sustainable urban development (environmental sustainability and social inclusion). Among the most important proposals of the Ministry is the proliferation of non motorized transport, in particular, the bicycle.

The federal Government implemented its understanding of the use of the bicycle as a mean of transport with the launch of an Brazilian program for bicycle mobility "Brazil Bicycle" on 22 September 2004 (Ordinance No. 399/2004). One of the main objectives of this program is to increase the use of bicycles within the urban transport-matrix [9].

\section{Non-motorised transport in Rio de Janeiro}

Rio de Janeiro is the Brazilian city that has been chosen for the development of this work. Among other reasons, Rio de Janeiro presents the most extensive bicycle path in the country, around $140 \mathrm{~km}$ (reference). Beyond this fact, Rio de Janeiro is a coastal city with colorful natural beauty which enforces a lot of people to practice outdoor sports. Further, Rio is the place for national and international sporting events, recently the Olympic Games of 2016 [11].

Other positive aspect to the cyclist of Rio de Janeiro is the availability of infrastructure that has been improved with the local government support. In December 2008, Rio de Janeiro became the first city in Brazil to implement a program whose mainly objective is to realize and important integration between the bicycle and the bus, train and underground, named "Pedal Rio". Meanwhile the project Samba (Alternative Solution for Mobility through Rental Bicycles) is implemented. This program realized the availability of rentable bikes in underground stations in several parts of the city [12].

Rio de Janeiro has been chosen in order to quantify the benefits of bicycle use instead of cars, including 13 south area districts (Copacabana, Ipanema, Leblon, Leme, Urca, Botafogo, Flamengo, Glória, Humaitá, Jardim Botânico, Catete, Laranjeiras and Gávea), these districts are mainly characterized by a residential and commercial infrastructure as well as the city center which concentrates most parts of commercial and financial activities. Between Those districts there are around $122 \mathrm{~km}$ of bicycle path and an intense daily flow of people. Altogether, 
the 14 districts that have been analyzed, present 610 thousand inhabitants, 245 thousand residences. The local fleet was calculated based on the information that each residence has in average one vehicle, this result in a fleet with 245 thousand automobiles[14].

\section{Methodology}

The methodology used to calculate the benefits derived from the replacement of automobiles with bicycles in the researched area of this work is realized in three steps:

- Calculating the distance travelled by automobile per year.

- Calculating the automobiles potentially replaced through bicycles.

- Calculating the benefits from the use of bicycles.

\subsection{Annual distance travelled by car}

To calculate the annual distance travelled by an automobile in the considered area (South Area and Downtown) the "report Urban Mobility Information System", was used. This report was published by the "National Association of public transportation" (ANTP) and presents information about the urban mobility per population band. Rio de Janeiro city, whose population is about 5.551.000 inhabitants, is classified in population band above 1 million of inhabitants [13].

According to the ANTP's report, in countries with a population of this dimension, the average distance travelled is $9 \mathrm{~km}$, in case of individual transport, while the number of trips per day per inhabitants is 2,4 [15]. So the distance travelled each day per inhabitant by automobile is $21,9 \mathrm{~km}$. Considering that the fleet of the study area comprises 245 thousand automobiles, the total distance travelled daily by cars is 5.348 thousand $\mathrm{km}$, or 1.358 million $\mathrm{km}$ in the year.

Table 1: Calculation of the total distance travelled by gasoline vehicles (2008).

\begin{tabular}{|l|c|}
\hline Variable & Total \\
\hline Distance for trip $(\mathrm{km})(\mathrm{a})$ & 9 \\
\hline Trips for inhabitants per day (unit) $(\mathrm{b})$ & 2 \\
\hline Distance for inhabitants per day $(\mathrm{km})(\mathrm{a}) \mathrm{x}(\mathrm{b})=(\mathrm{c})$ & 22 \\
\hline Fleet of automobiles $\left(10^{3}\right.$ units) $(\mathrm{d})$ & 245 \\
\hline Working days in the year(e) & 254 \\
\hline Annual total distance of the fleet $\left(10^{3} \mathrm{~km}\right)(\mathrm{c}) \times(\mathrm{d}) \times(\mathrm{e})=(\mathrm{f})$ & 1.358 .426 \\
\hline Ratio of the use of the gasoline for automobiles $(\mathrm{g})$ & $86 \%$ \\
\hline Annual total distance of the fleet with gasoline use $\left(10^{3} \mathrm{~km}\right)(\mathrm{f}) \times(\mathrm{g})=(\mathrm{h})$ & 1.168 .246 \\
\hline
\end{tabular}

At this point it must be emphasized that the Brazilian vehicle fleet consist of gas and flex fuel vehicles, which can use gasoline or ethanol at any desired mixture. However, the use of ethanol, considering only the emission of the 
combustion process, present a balance of carbon emission equal to zero, considering that during the plantation of sugar cane the $\mathrm{CO}_{2}$ was captured by the atmosphere. This is why, in this work the reduction of greenhouse gases through substitution of light automobiles through bicycles, only the distance travelled by vehicles using gasoline is estimated. It was estimated that $28 \%$ of the total car fleet are flex fuel and use alcohol $50 \%$ of the time. Hence in $86 \%$ of the time gasoline is used as fuel. From this fact follows that an annual distance of 1.168 million $\mathrm{km}$ is travelled using exclusively gasoline.

\subsection{Potential of replacement - automobiles through bicycles}

The calculation of the benefits of a potential replacement of automobiles through bicycles considers that, among the owners of automobiles in Rio de Janeiro city, those aged between 18 and 45 years, representing about $73 \%$ of all inhabitants, present more tendencies to use bicycle as a mean of transport [13]. Further, it is estimated that within this group of people, only a part would be receptive for this kind of program. The parameter was estimated with $73 \%$ during the public cultural research named "Rio na Cabeça", held in Rio de Janeiro between October and December of 2009 [16].

So, the total of automobiles that represent the potential of replacement, in the considered districts in this study, taking into account, the restriction of the population age and the proactivity related to the use of the bicycle is 129 thousand cars out, of the total fleet of 245 thousand of vehicles.

To calculate the total distance travelled by bicycles throughout the year was still considered that in rainy days, this kind of transport is not used. In 2008, the percentage of working days without rain in Rio de Janeiro was about 70\% [17], a total of 178 days in the year has been considered to the use of bicycle. Therefore the considerations given above, the potential annual distance travelled by bicycles in replacement to the displacements done by automobiles is about 505 million $\mathrm{km}$.

Table 2: $\quad$ Potential distance travelled by bicycles (2008).

\begin{tabular}{|c|c|c|c|}
\hline Variables & Total & Proportion & Potential \\
\hline $\begin{array}{l}\text { Potential of cars to be replaced by the use of bicycles } \\
\qquad\left(10^{3} \text { unit) (a) }\right.\end{array}$ & 245 & $53 \%$ & 130 \\
\hline Working days without rain in a year (unit) (b) & 365 & $49 \%$ & 178 \\
\hline Daily distance per inhabitant (km/inhab.) (c) & 22 & $100 \%$ & 22 \\
\hline $\begin{array}{l}\text { Annual distance per inhabitant }\left(10^{3} \mathrm{~km} / \mathrm{hab} \text {.) (a) } \mathrm{x}(\mathrm{b}) \mathrm{x}\right. \\
\text { (c) }=(\mathrm{d})\end{array}$ & 1.945 .813 & $26 \%$ & 505.180 \\
\hline Ratio of the gasoline use per automobiles (e) & - & $86 \%$ & - \\
\hline $\begin{array}{l}\text { Annual distance travelled by bicycle by replacing } \\
\text { gasoline car usage }\left(10^{3} \mathrm{~km}\right)(\mathrm{d}) \mathrm{x}(\mathrm{e})=(\mathrm{f})\end{array}$ & - & - & 434.455 \\
\hline
\end{tabular}

However, according to the explanation in the previous item, around $14 \%$ of this distance refers to the use of ethanol; soon the remaining $(86 \%)$ is effectively related to the distance travelled using gasoline as a fuel which is equal to $434.707 .839 \mathrm{~km}$. 


\section{Results}

The benefits raised due to the use of bicycle replacing the movements fulfilled by automobiles quantified in this study are:

- Reduction in the consumption of fossil fuel (gasoline)

- Reduction of private costs spending for fuel (gasoline)

- Reduction of $\mathrm{CO}_{2}$ emission

- Reduction of accidents

The results derived in this paper are exclusively related to the region proposed in this study, represented by the fourteen districts of Rio de Janeiro city. Parameters and statistics used are based on the year 2008.

\subsection{Reduction of gasoline consume}

The reduction of fuel consume considers the kilometers annually travelled by bicycles $(434.707 .839 \mathrm{~km})$ substituting automobiles, linked to an average efficiency of cars in urban traffic conditions $(7 \mathrm{~km} /$ liter $)$ [15]. The result is a possible avoidance of gasoline combustion of 62,1 million liters per year, compared to a total consumption of 167 million liters without the substitution of cars through bicycles.

\subsection{Reduction of private fuel cost}

For automobile user, there is a direct cost for the gasoline consumption, which varies according to the price of this fuel in the local supply. In Rio de Janeiro, in 2008 , the average price of gasoline was 1,36 US\$/liter, according to the National Oil, Natural Gas and Biofuel Agency [9]. Therefore the direct costs saved by the avoidance of automobile use was US\$ 84, 3 million in 2008, compared with the value of US\$ 227 million without the project.

\subsection{Reduction of $\mathrm{CO}_{2}$ emission}

The emission of $\mathrm{CO}_{2}$ as well as accidents caused by the use of individual transport, are estimated by a factor named negative externality. This is because, the negative impact of the decision to use a car by a certain person, does not only affect himself but as well others that were not involved in the decision.

The emission of greenhouse gases (GHG) of the gasoline used in Brazil is reduced by the anhydrous alcohol content added, which varies between $20 \%$ to $25 \%$ in accordance to the current legislation period. According to the Energy Research Enterprise (EPE) [19], for each liter of gasoline 2,264 $\mathrm{kg}$ of $\mathrm{CO}_{2}$ are emitted, taking into account a proportion of $23 \%$ of anhydrous alcohol in gasoline. This way, the reduction of $\mathrm{CO}_{2}$ equivalent due to a decreasing car use is 140.596 tones (as shown in Table 3), that means a reduction of $37 \%$ compared to the figure without the use of non-motorized transport (378 million tones of $\mathrm{CO}_{2}$ ). 
Table 3: Reduction of gasoline consumption, $\mathrm{CO}_{2}$ emissions and avoided gasoline expenses.

\begin{tabular}{|c|c|}
\hline Variables & Results \\
\hline Distance traveled by bicycle replacing gasoline cars $(\mathrm{km})(\mathrm{a})$ & 434.707 .839 \\
\hline Car average efficiency considering urban traffic conditions $(\mathrm{km} /$ liter $)(\mathrm{b})$ & 7,0 \\
\hline Avoided gasoline consumption (liters) $(\mathrm{a}) \mathrm{x}(\mathrm{b})=(\mathrm{c})$ & 62.101 .120 \\
\hline Emission rate $\left(\mathrm{kg}\right.$ of $\mathrm{CO}_{2} /$ liter $)(\mathrm{d})$ & 2,3 \\
\hline Avoided emission (ton of $\left.\mathrm{CO}_{2}\right)(\mathrm{c}) \mathrm{x}(\mathrm{d})=(\mathrm{e})$ & 140.596 .935 \\
\hline Gasoline cost in RJ (average price 2008$)(\mathrm{US} \$ /$ liter $)(\mathrm{f})$ & 1,4 \\
\hline Avoided gasoline cost $(\mathrm{US} \$)(\mathrm{c}) \times(\mathrm{f})=(\mathrm{g})$ & 84.457 .522 \\
\hline
\end{tabular}

\subsection{Reduction of accidents}

ANTP quantifies the cost of accidents related to the use of individual transport. In 2007, according to the organization, the cost of externalities in Brazil, associated to accidents with automobiles completed about US\$ 2,7 billion. In accordance with Brazilian average parameters, the cost of accidents per automobiles is US\$ 177,3 per year [15]. However considering the cost of accidents by cities according to the population range, it is possible note that in more populate cities, the cost of accidents per inhabitant is great.

In the case of the area of study, whose population is above 1 million of inhabitants, the cost of accidents is US\$ 36, 7 per inhabitant, that results in a total annual cost of US\$22, 2 million per year. Through the use of bicycles, the

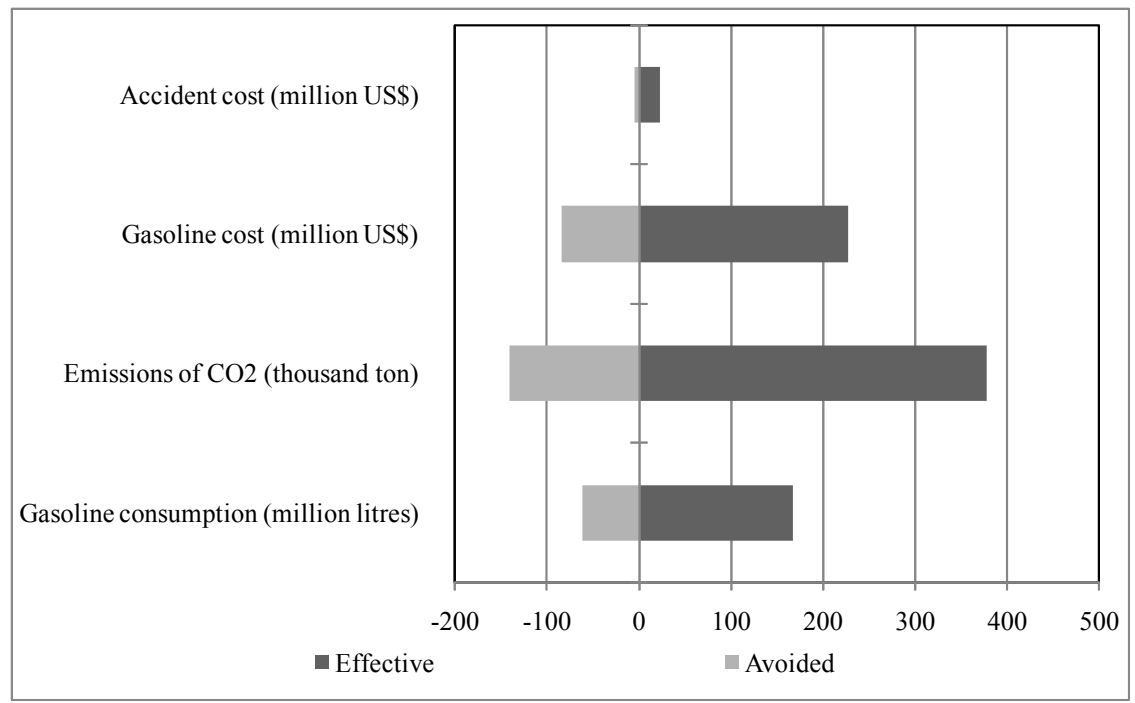

Figure 2: Benefits of the use of the bicycle in substitution to the use of the automobile according to parameters chosen. 
cost related to accidents with automobiles is reduced in US\$ 4,86 million per year. Beyond the monetary value registered other disturbing caused by physical and emotional consequences related to these accidents are not measurable.

In Figure 2, it is possible to see the values found with the parameters used, which were evaluated without the use of the bicycle, that would be avoided if the use of the bicycle replace the displacement of automobiles, according to the estimated potential, $53 \%$.

Other benefits of the use of the bicycle as a mean of transport are very important, even though they are not considered in the objectives of this analysis. Benefits as reduction of noise pollution related to the use of automobiles, decreasing of waste of urban space for road transport (including infrastructure of roads and parking) and the improvement of the physical condition and the health of the inhabitants.

\section{Conclusion}

The concept of urban mobility is an advance in segmented way of dealing with the transit, the collective transport, the logistics and the distribution of goods, the construction of road infrastructure and other issues related to urban constrains in Brazil. The processing of the transformation of that concept into something tangible needs to be consolidated in a systemic view that considers all the movement of goods and people, involving all modes and all elements that produce the needs of mobility.

The inclusion of bicycle in urban areas must be approached as an element for insertion to the concept of urban mobility for sustainable cities as a way of reducing pollutants, and improving the health of the population, beyond the social inclusion. Bicycle's integration in the current systems of moving is possible, but it must be considered as an integrated element of a new urban design, that behold the implantation of infrastructures, as well as new thoughts about the urban land use.

Although this work does not aim to quantify disadvantages in the use of bicycle in trade-off the automobile, it is important to emphasize that there are some features which limit the population to be a membership of this kind of transport such as: greater susceptibility to climate change, limited length and time of the trip. Regarding to the length of the trip, there is a restriction derived from the physical effort. However, there is some difficulty in define the maximum length, due to the large variation of the factors that influence them. On the one hand, the capacity, and the fitness of each person and on the other hand, some characteristics of the city, such as: topography and road infrastructure. Furthermore, the limited trip extension can be a favorable factor when the bicycle is used as a complementary means of transport and is integrated to terminal transports.

The time of the trip also presents a variability according to the physical conditioning of the people and the road bike characteristics. According to the information of the "Ministry of Cities", in normal condition, considering the friction in the crossing roads and in other circumstances of traffic, the average 
speed of bicycle stays between $12 \mathrm{~km} / \mathrm{h}$ and $15 \mathrm{~km} / \mathrm{h}$. At this point, the worst is the local traffic condition; more competitive is the bicycle relating to the variable time.

It should be emphasized, however, that the time spent in the offset by bicycle, means that physical exercise that contributes to restore and maintain the physical and mental well-being of the population. Surveys show that physically active individuals tend to present less chronic-degenerative diseases, result of a series of physiological and psychological benefits derived from the practice of physical activity.

In case of Rio de Janeiro city, it is possible to note that aspects related to infrastructure (interconnection bike roads, improvements in signposts and installation of support for parking bicycles) and security (policing, lighting areas more susceptible to theft and robbery) are fundamental to enlarge the base of bicycle transport users.

However, despite the many limitations, it is emphasized that Rio de Janeiro has some characteristics that make it a good area to increase the transport by bicycle as: low percentage of rainy days in the year (only 30\% in 2008), $140 \mathrm{~km}$ of road bike, level embossed in most of its extent and favorable conditions for the practice of sports.

The quantification of benefits arising from the use of non-motorized transport, particularly the bicycle, in trade-off car usage, in the 14 selected neighborhoods of Rio de Janeiro city, in the year 2008, shows the importance of this measure for the sustainable development of urban centers. It was noted that the potential for reducing the consumption of gasoline would be 62 million of liters, which is the issue of 141.000 tones of $\mathrm{CO}_{2}$ that could be avoided. On the other hand, private spending with gasoline consumption could be reduced in US\$84 million and various automobile accidents might not happen, avoiding beyond physical and emotional conflicts, the equivalent of US\$ 5 million.

\section{References}

[1] European Environment Agency [EEA], 2009. "Transport at a crossroads. Term 2008: indicators tracking transport and environment in the European Union." Copenhagen (Dinamarca): EEA. Disponível em: http://www.eea.europa.eu/.

[2] Mozer, D, 1993. "Leveling the Playing Field." Seattle (US): International Bicycle Fund. Disponível em: <http://www.ibike.org/engineering/ landuse.htm>.

[3] Agência Nacional do Petróleo, Gás Natural e Biocombustíveis [ANP], 2009a. Dados Estatísticos. Vendas de Combustíveis. Disponível em: < http://www.anp.gov.br/petro/dados_estatisticos.asp>.

[4] Organisation for Economic Co-operation and Development [OECD], 2009. "About OECD". Paris: OECD. Disponível em: <http://www.oecd.org/ pages $/ 0,3417$,en_36734052_36734103_1_1_1_1_1,00.html $>$.

[5] Energy Information Administration [EIA], 2009. "Annual Energy Outlook 2009”. Washington, D.C.: EIA/DOE. Disponível em: $<$ http://www.eia.doe.gov/oiaf/aeo/>. 
[6] European Commission [EC], 2008a. "EU Energy and Transport in Figures 2007/2008." Statistical PocketBook. Luxemburgo: EC. Disponível em: $<$ http://europa.eu>.

[7] European Commission [EC], 2008b. "Eurostat 2008. Energy, transport and environment indicators". Luxemburgo: EC. Disponível em: $<$ http://epp.eurostat.ec.europa.eu/portal/page/portal/publications/recently_p ublished $>$.

[8] World Bank [WB], 2008. "Gross national income per capita 2008". The World Bank Group. Washington, D.C. Disponível em: $<$ http://siteresources.worldbank.org/DATASTATISTICS/Resources/GNIP C.pdf> Acesso em: 02-12-2009.

[9] Ministério das Cidades [MC], 2007. "Programa Brasileiro de Mobilidade por Bicicleta - Bicicleta Brasil”. Brasília: Secretaria Nacional de Transportes e da Mobilidade Urbana/MC. Disponível em: < www.cidades.gov.br>.

[10] Prefeitura do Rio de Janeiro, 2009. Guia do Rio. Disponível em: http://www.rioguiaoficial.com.br/esportes/com $+140+\mathrm{km}+\mathrm{de}+$ ciclovia+bicic leta + excelente + op $+o+$ para + conhecer $+o+$ rio/03+08+2009/33/

[11] Rio 2016, 2009. Disponível em: http://www.rio2016.org.br/pt/Default.aspx.

[12] Mobilicidade, 2009. Portal da Mobilidade Urbana. Disponível em: http://www.mobilicidade.com.br/.

[13] Instituto Brasileiro de Geografia e Estatística [IBGE], 2007a. "Contagem da População 2007." Disponível em: http://www.ibge.gov.br/home/ estatistica/populacao/contagem2007/defaulttab.shtm.

[14] Instituto Brasileiro de Geografia e Estatística [IBGE], 2007b. Pesquisa de Orçamentos Familiares 2002-2003. Perfil das Despesas no Brasil. Indicadores Selecionados. Disponível em: <www.ibge.gov.br>.

[15] Associação Nacional de Transportes Públicos [ANTP], 2008. "Sistema de Informações da Mobilidade Urbana. Relatório Geral 2007”. Brasília: ANTP. Disponível em: <http://portall .antp.net/site/default.aspx >.

[16] O GLOBO, 2009. Concurso Cultural Rio na Cabeça. Disponível em: http://oglobo.globo.com/blogs/rionacabeca/.

[17] MAPS GUIDES, 2010. Brasil - Previsão Metereológica - Rio de Janeiro. Disponível em: http://www.mapsguides.com/w/brasil_previsao_ meteorologica_rio_de_janeiro_pt.php..

[18] Agência Nacional do Petróleo, Gás Natural e Biocombustíveis [ANP], 2009b. Anuário Estatístico Brasileiro do Petróleo, Gás Natural e Biocombustíveis. Disponível em: < http://www.anp.gov.br/ $? \mathrm{pg}=15537 \& \mathrm{~m}=\& \mathrm{t} 1=\& \mathrm{t} 2=\& \mathrm{t} 3=\& \mathrm{t} 4=\& \mathrm{ar}=\& \mathrm{ps}=\&$ cachebust $=1264694856638$.

[19] Empresa de Pesquisa Energética (EPE), 2008. Potencial de redução de emissões de $\mathrm{CO}_{2}$ em projetos de produção e uso de biocombustíveis. Disponível em < http://www.epe.gov.br/Petroleo/Documents/Estudos_29/ EPE\%20-\%202\%C2\%BA\%20Biocombust\%C3\%ADveis\%20x\% 20MDL.pdf. 